\title{
An Overview of the Grapefruit Market in South Korea ${ }^{1}$
}

\author{
Yan Heng, Hyeyoung Kim, and Lisa House 2
}

\section{Introduction}

According to the Foreign Agricultural Service of the United States Department of Agriculture (USDA/FAS 2016), worldwide consumption of fresh grapefruit has grown from 4.2 million metric tons (MT) in 2010/11 to 5.2 million MT in 2014/15. The increase in consumption is mostly attributed to China, which is also the largest producer, and therefore does not impact the international market to a large degree. (The numbers reported by USDA/FAS do not distinguish between grapefruit and pomelo, but generally the production and consumption in China are attributed to pomelo, while the production and consumption in other countries are attributed to grapefruit.) Estimated grapefruit consumption in China was 3.8 million MT in 2014/15, followed by the European Union (EU) with 435,000 MT. Consumption in many other countries decreased between 2010/11 and 2014/15. For example, consumption of grapefruit in Japan, a major importer of grapefruit, decreased by $40 \%$, while consumption in the United States and Canada decreased by approximately $16 \%$ and $10 \%$, respectively. Many factors are pressuring grapefruit consumption, such as price, changes in consumer preferences, and competition from other fruit categories. Particularly, the reported interaction effect of grapefruit with certain medications, such as cholesterol drugs, may prevent the older population from consuming the fruit, while the younger population may prefer grab-and-go fruits and sweeter taste.

On the production side, there have also been major changes. In the United States, the second largest producer of

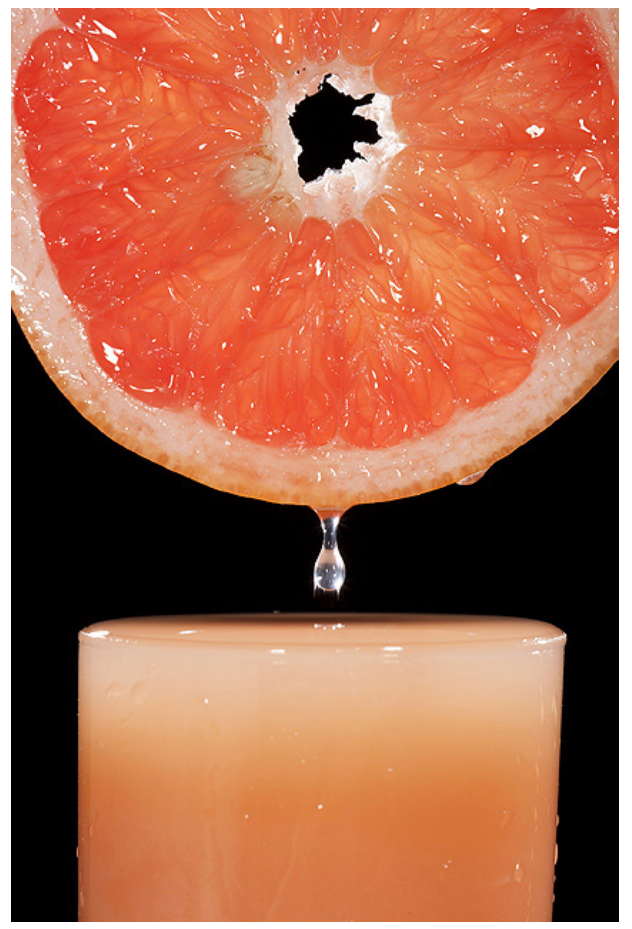

Credits. USDA/ARS

grapefruit, production decreased $26 \%$ in 2014/15 compared to $2010 / 11$ and $75 \%$ since the 1980 s. This decline is largely attributed to acreage losses and citrus greening disease, particularly in Florida, the largest producer of grapefruit in the United States (USDA/ERS 2015c). In 2014/15, production of Florida grapefruit was 548,000 MT, a decline of nearly 35\% compared to 2010/11 (Florida Department of Agriculture and Consumer Services [FDACS] 2016). Other major producers include Mexico and South Africa, each with approximately 400,000 MT in 2014/15.

1. This is EDIS document FE1003, a publication of the Food and Resource Economics Department, UF/IFAS Extension. Published February 2017. Visit the EDIS website at http://edis.ifas.ufl.edu.

2. Yan Heng, post-doctoral associate; Hyeyoung Kim, assistant research scientist; and Lisa House, professor, Food and Resource Economics Department, UF/IFAS Extension, Gainesville, FL. Support for this study was provided by the Florida Department of Citrus.

The Institute of Food and Agricultural Sciences (IFAS) is an Equal Opportunity Institution authorized to provide research, educational information and other services

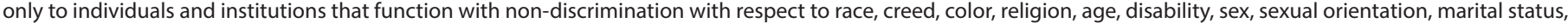
national origin, political opinions or affiliations. For more information on obtaining other UF/IFAS Extension publications, contact your county's UF/IFAS Extension office. U.S. Department of Agriculture, UF/IFAS Extension Service, University of Florida, IFAS, Florida A \& M University Cooperative Extension Program, and Boards of County Commissioners Cooperating. Nick T. Place, dean for UF/IFAS Extension. 
Regarding trade, the major grapefruit exporters include the United States, South Africa, and Turkey. The European Union is the largest importer of grapefruit, followed by Russia and Japan (USDA/FAS 2016). The United States exports fresh grapefruit to Japan, the European Union, Canada, and South Korea. Within the United States, Florida is the major exporting US state, accounting for 72\% of US exports in 2014 (FDACS 2015). However, export trends for US grapefruit have been changing. Due to the shrinking domestic market and weakened local currency, US grapefruit exports to Japan and the European Union have decreased $65 \%$ and $35 \%$, respectively. However, South Korea has become a fast-growing market for US citrus. This study aims to provide an overview of the grapefruit market in South Korea and evaluate the potential of this market for Florida fresh grapefruit producers using a consumer survey.

\section{Fresh Fruit Market in South Korea}

South Korea ranked eleventh by nominal gross domestic product (GDP) in the world in 2015, with US $\$ 1,393$ billion. The growing buying power leads to consumers' interests in food quality and diet diversity, reflecting consumers' demand for healthy food. South Korea produces various vegetables and fruit, and the value of fresh vegetables and fruit accounts for nearly one-third of the total agricultural output value in this country. However, nearly $80 \%$ of Korea's fruit production in 2014 was limited to five major items: tangerines $(26.8 \%)$, apples $(17.6 \%)$, grapes $(13.7 \%)$, Asian pears (11.2\%), and peaches (7.8\%). Moreover, domestic producers no longer fully satisfy Korean consumers' growing demand and taste changes. As an example of this, per-capita fruit consumption in South Korea increased from 41.8 kilograms $(\mathrm{kg})$ in 1990 to $66.5 \mathrm{~kg}$ in 2014, whereas the share of per-capita fruit consumption decreased from $88.3 \%$ to $60.0 \%$ during this period (Ministry of Agriculture, Food and Rural Affairs [MAFRA] 2016).

South Korea has reduced import barriers for fruit to meet consumers' growing demands. Fruit imports increased from US\$825 million in 2000 to US\$1,640 million in 2014 (Korea International Trade Association 2016). The United States has been a major exporter of agricultural products to South Korea for decades. South Korea was the fifth largest US importer in 2013, with US\$5.24 billion in agricultural purchases (USDA/ERS 2015b). South Korea imports various US fruits, including oranges, grapefruit, lemons, grapes, and sweet cherries. Although the harvest season for many fruits is the same in the United States and South Korea, US producers are finding markets in South Korea because of the higher-quality fruit and lower costs (USDA/ERS 2015a).

\section{Grapefruit Market in South Korea}

South Korea first imported grapefruit from the United States in 1988, with imports peaking in 1989. For the decade that followed, South Korean imports of US grapefruit declined because of a misinterpreted laboratory test on grapefruit for Alar, a chemical with a potential for causing cancer. Even though the mistake was corrected, it took time for consumer perception of US grapefruit to improve. Grapefruit imports eventually increased, reaching a historical record of 19,491 MT in 2014. As the increasing trend continued in 2015, the share of imports from the rest of the world also began to increase, from 10\% in 2010 to $43 \%$ in 2015. Monthly grapefruit imports from the United States and the rest of the world between 2010 and 2015 are shown in Figure 1.

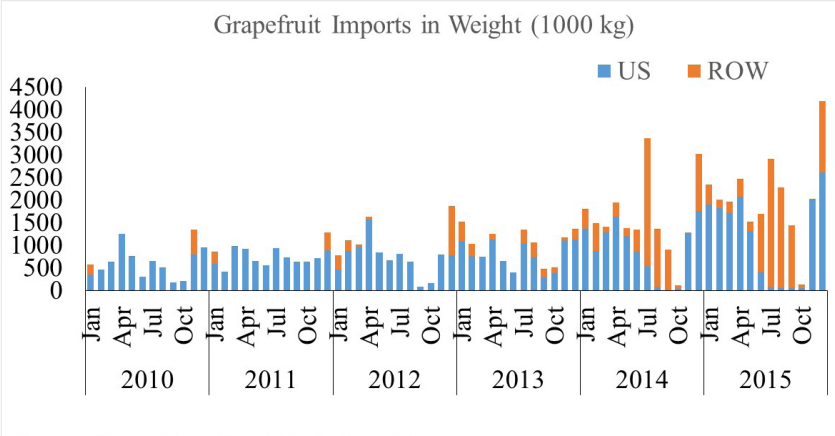

Source: Korea International Trade Association

Figure 1. Grapefruit imports of South Korea from the United States and the rest of the world (ROW), 2010-2015

South Korean consumers have shown an interest in grapefruit due to its low caloric/sugar content and high vitamin $\mathrm{C}$ content. There is a trend of demand shifting from lemons to grapefruit because of grapefruit's less sour taste and competitive price compared to lemons (USDA/FAS 2015). The beverage industry and restaurants have developed various products using grapefruit, such as grapefruit beer and ice cream in summer and grapefruit "chuang" in winter.

South Korea imported 23,087 MT of grapefruit in 2014/15, with imports estimated to increase to $25,000 \mathrm{MT}$ in 2015/16. During 2006-2014, exports of Florida grapefruit to South Korea increased 550\% (FDACS 2015). Figure 2 shows that current major grapefruit exporters to South Korea are the United States and South Africa, accounting for $54 \%$ and $34 \%$ of market shares in 2014/15 season, respectively.

South Korea imports fresh grapefruit from Florida from October to March, from California from April to June, and from South Africa from May to September. While the harvest season in South Africa is different from other 
exporters, US fresh grapefruit competes head-to-head with red grapefruit from Israel, in particular, the variety Star Ruby (often called "Sweetie"). Grapefruit imports from South Africa and Israel have increased dramatically since 2012/13 to meet the increasing demand, creating more competition for US grapefruit. Until 2013, US market share accounted for over $80 \%$ of the grapefruit imported to South Korea; in 2014, US market share was only $56 \%$. One reason for the decrease in US market share is that the import price of US grapefruit is higher than grapefruit imported from Israel and South Africa. This problem may be alleviated in the future through the US-Korea Free Trade Agreement, which was implemented in 2012. Under this Agreement, the $30 \%$ tariff rate on US grapefruit will be reduced to zero in five equal annual installments, which should help US grapefruit gain back its market share gradually.

Grapefruit Imports in Volume (MT)

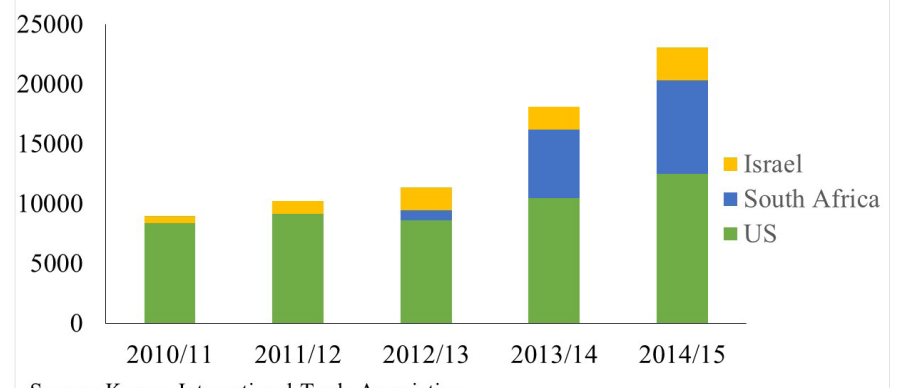

Source: Korean International Trade Association

Figure 2. Grapefruit imports in volume, by source, 2010/11-2014/15

\section{South Korea Grapefruit Consumer Survey}

To benefit Florida grapefruit producers and exporters, the Florida Department of Citrus is focusing on export promotions in South Korea. As part of the monitoring of this program, a national online survey was conducted in 2015 regarding South Korean consumer trends related to grapefruit consumption, as well as consumer perception of US grapefruit. The targeted consumers in the survey were female shoppers over 20 years of age who were responsible for household food purchases. The survey consisted of questions regarding purchase decisions, shopping behavior, and consumption and perception of grapefruit. A validation question was used to ensure the quality of the responses to the survey (Jones, House, and Gao 2015). Demographic information, including age, education, marital status, and employment were also collected (Table 1).

A sample of 992 respondents was collected. Within the sample, about $26 \%$ of respondents reported purchasing grapefruit in the last six months (defined as active consumers). Of these active consumers, nearly $70 \%$ consumed grapefruit at least once per month (Figure 3). In the survey, the top three factors that influence consumers' grapefruit purchases were freshness $(67 \%)$, good value $(60 \%)$, and sweetness (50\%).

Consumption Frequency of Grapefruit

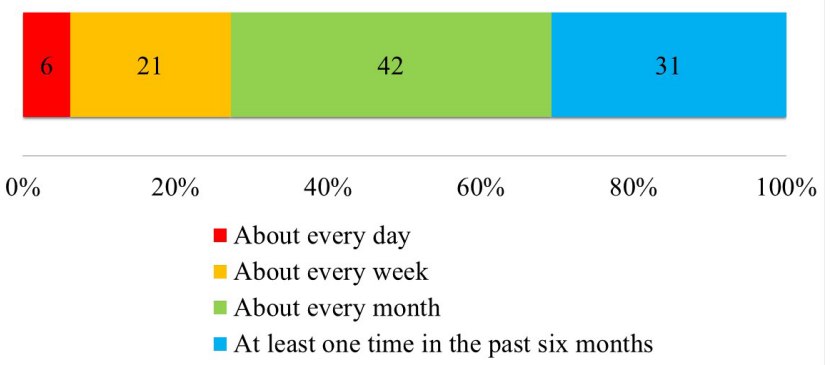

Figure 3. Consumption frequency over the last six months

The most popular occasions to consume grapefruit in South Korea were desserts and snacks (Figure 4). Of respondents who purchase or intend to purchase grapefruit, $70 \%$ ate or would eat grapefruit as a dessert, and $54 \%$ ate or would eat grapefruit as a snack.

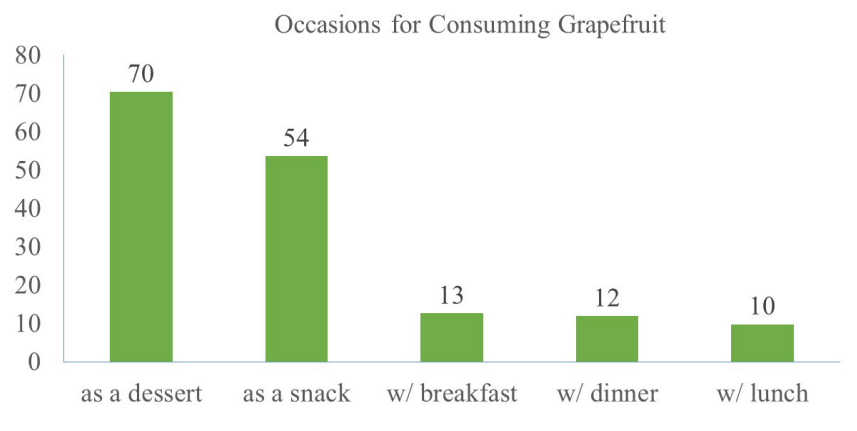

Figure 4. Occasions for consuming grapefruit

About $40 \%$ of respondents were aware that California and Florida produce grapefruit. Nearly half of the total respondents indicated that they would definitely or probably would buy grapefruit in the upcoming year (Figure 5). Of the respondents who had purchased or intended to purchase grapefruit, $67 \%$ indicated they would definitely or probably buy Florida grapefruit in the upcoming year. Respondents indicated that the major factors that would increase purchases of Florida grapefruit were price promotions (50\%), better quality (48\%), and better taste (43\%).

Unlike traditional markets where consumers tend to be older, the survey showed that South Korean active grapefruit consumers consisted of younger respondents. Table 2 
shows the distribution of respondents by age and consumer type. The upper section compares grapefruit consumers and non-grapefruit consumers, where grapefruit consumers are defined as consumers who either purchased grapefruit in the past six months (active consumers) or those who did not purchase in the past six months but purchased in the past two years (lapsed consumers), and non-grapefruit consumers are defined as consumers who did not purchase grapefruit in the last two years. The bottom section compares active grapefruit consumers and lapsed grapefruit consumers. T-tests are used to test for the age differences between the two types of consumers. Results show that a larger proportion of senior consumers (ages 50 years old and above) have consumed grapefruit in the past two years, but consumers ages 30-39 years old are significantly more likely to be active consumers. Such results indicate that senior consumers are likely to stop purchasing grapefruit, while younger consumers are likely to continue purchasing grapefruit in the current Korea market.

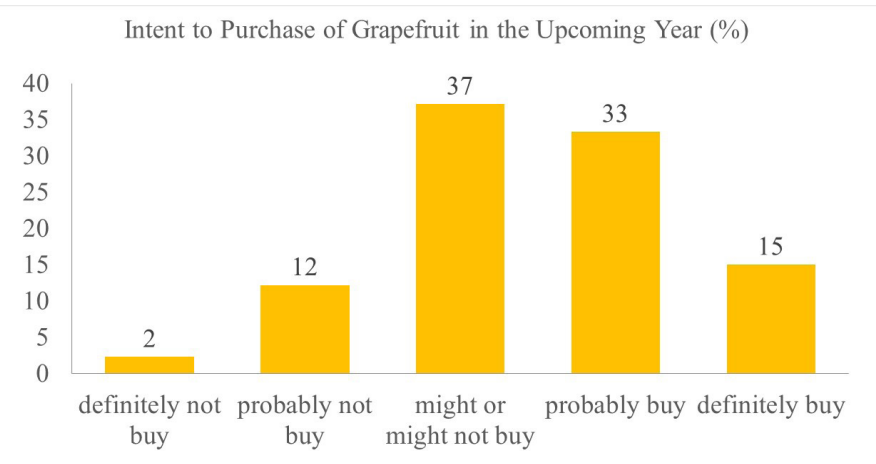

Figure 5. Percentage of potential consumers

\section{Summary}

The South Korean grapefruit market has been increasing in recent years and is expected to keep growing. Traditionally, the United States has dominated the Korean grapefruit market but is facing fierce competition from other suppliers with lower import prices and different harvest seasons. According to a survey conducted with consumers in South Korea, grapefruit is perceived as a healthy food that supports the immune system. The United States is recognized as the top grower of grapefruit and source of purchased grapefruit. Price and quality are key factors that influence consumers' grapefruit purchases. The implementation of the US-Korea Free Trade Agreement (which will gradually phase out the $30 \%$ grapefruit tariff on US grapefruit) should decrease prices for US grapefruit in South Korea. Even with the lower price, US grapefruit market share will continue to decline due to citrus greening in US grapefruit-production areas.
South Korean grapefruit consumers tend to be younger compared to traditional markets and usually consume grapefruit in drinks, snacks, and desserts. Some older consumers leave the grapefruit market due to the interaction effect between grapefruit and medications, so the market is dependent on younger consumers. More research needs to be conducted to see whether the increase in consumption among young consumers in South Korea can be replicated in other parts of the world.

\section{References}

FDACS. 2016. Florida citrus statistics 2014/15. Tallahassee, FL: Food Department of Agriculture and Consumer Services. https://www.nass.usda.gov/Statistics_by_State/ Florida/Publications/Citrus/Citrus_Statistics/2014-15/ fcs1415.pdf

FDACS. 2015. 2015 international report. Tallahassee, FL: Food Department of Agriculture and Consumer Services. http://www.freshfromflorida.com/content/download/59882/1184512/2015_International_Report.pdf.

Jones, M., L. House, and Z. Gao. 2015. "Respondent screening and SARP: Testing quarantining methods for better data quality in web panel surveys." Public Opinion Quarterly 79(3):687-709.

Korea International Trade Association. 2016. K-statistics, by commodity, all countries. http://www.kita.org/kStat/ byCom_AllCount.do.

MAFRA. 2016. 2015 yearbook of agricultural and livestock food. Seoul, South Korea: Ministry of Agriculture, Food, and Rural Affairs.

USDA/ERS. 2015a. "Specialty and Processed Product Markets." Washington, DC: United States Department of Agriculture, Economic Research Service. http://www.ers. usda.gov/topics/international-markets-trade/countriesregions/south-korea/specialty-processed-product-markets. aspx.

USDA/ERS. 2015b. "South Korea: Trade." Washington, DC: United States Department of Agriculture, Economic Research Service. http://www.ers.usda.gov/topics/international-markets-trade/countries-regions/south-korea/trade. aspx.

USDA/ERS. 2015c. "Fruit and Tree Nuts Outlook." Washington, DC: United States Department of Agriculture, Economic Research Service.

USDA/FAS. 2016. "Citrus: World Markets and Trade." Washington, DC: United States Department of Agriculture, Foreign Agricultural Service. Retrieved from http://apps. fas.usda.gov/psdonline/circulars/citrus.pdf 
Table 1. Summary statistics for demographic measures

\begin{tabular}{|lll|}
\hline Variables & Description & South Korea \\
\hline Age & Ages 20 to 29 years old & $23 \%$ \\
& Ages 30 to 39 years old & $30 \%$ \\
& Ages 40 to 49 years old & $26 \%$ \\
Education & Age 50 years old and above & $61 \%$ \\
Marital status & Bachelor or higher degree & $69 \%$ \\
Employment & Married & $47 \%$ \\
\hline
\end{tabular}

Table 2. Age differences: Active versus non-active consumers, active versus lapsed consumers

\begin{tabular}{|c|c|c|c|c|}
\hline Age & & & t-stat & $p$-value \\
\hline Active vs Non-Active Consumers & Non-GF Consumer & GF Consumer & & \\
\hline Ages 20 to 29 years old & 0.22 & 0.21 & 0.13 & 0.89 \\
\hline Ages 30 to 39 years old & 0.22 & 0.22 & 0.22 & 0.83 \\
\hline Ages 40 to 49 years old & 0.31 & 0.29 & 1.05 & 0.29 \\
\hline Age 50 years old and above & 0.22 & 0.29 & -2.17 & 0.03 \\
\hline Active vs Lapsed Consumers & Lapsed & Active & & \\
\hline Ages 20 to 29 years old & 0.22 & 0.21 & 0.13 & 0.89 \\
\hline Ages 30 to 39 years old & 0.19 & 0.26 & -2.08 & 0.04 \\
\hline Ages 40 to 49 years old & 0.30 & 0.27 & 0.63 & 0.53 \\
\hline Age 50 years old and above & 0.30 & 0.25 & 1.14 & 0.25 \\
\hline
\end{tabular}

